\title{
The effects of the forage preservation methods on fermentation parameters in ruminal fluid of fattening bulls
}

\author{
J. Jatkauskas ${ }^{1}$ and V. Vrotniakienė \\ Department of Animal Nutrition and Feeds, \\ Institute of Animal Science of Lithuanian Veterinary Academy \\ R. Žebenkos 12, LT-82317 Baisogala, Radviliškio r., Lithuania
}

\begin{abstract}
Treatment F (inoculant) produced more and treatment A (chemical additive) produced less fermentation products compared with untreated (C) silage. Treatment A preserved more WSC and treatment $\mathrm{F}$ produced more lactic acid. Fattening bulls were offered silages ad libitum. When ruminal fluid samples were analysed the number of protozoa tended to be higher with A treated silage. Rumen $\mathrm{pH}$, ammonia-N, total VFA did not differ between the diets in mean values, but the proportion of acetate was significantly lower $(\mathrm{P}<0.05)$ with $\mathrm{F}$ treated silage and the proportion of propionate was significantly higher $(\mathrm{P}<0.01)$ when $\mathrm{F}$ and $\mathrm{A}$ silages were fed compared with $\mathrm{C}$ silage.
\end{abstract}

KEY WORDS: silage, rumen, fermentation, fattening bulls

\section{INTRODUCTION}

When herbage is preserved as silage, WSC of the grass are fermented to lactic acid and VFA (McDonald et al., 1991). The extent of fermentation of WSC during ensilage into lactic acid and VFA can change the end-products of rumen fermentation. The majority of published reports indicate that propionate is the main end-product of lactate fermentation with grass silage-based diets (Jaakkola et al., 1991). Diets based on restrictively fermented grass silages which are high in water WSC and low in lactate, favour a rumen fermentation pattern rich in butyrate or acetate and low in propionate. Silages low in WSC and high in lactic acid have increased the proportion of propionate in ruminal fluid (Cushnahan et al., 1995). Ruminal fluid of animals fed only silages were marked by higher coefficients of rumen transformations as well as higher number of protozoa (Krzywiecki et al., 2003). In the majority of trials reported in the literature, the silages treated with inoculants appeared to be more digestible than the untreated silages (McDonald

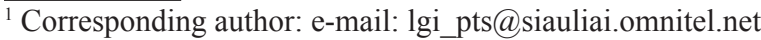


et al., 1992). It seems that the ingestion of silage fermentation end products may modify the rumen fermentation pattern and nutrient digestion.

A study was carried out to determine the effects of silage additives on extents of silage fermentation in big bales and assess how silages with different levels of fermentation end products are related with ruminal fermentation parameters and nutrient digestion.

\section{MATERIAL AND METHODS}

A second cut of mixed red clover (72\%) - timothy (20\%) - meadow fescue (5\%) sward, with the mean dry matter (DM) content of $180 \mathrm{~g} \mathrm{~kg}^{-1}$, mean total nitrogen (TN) and water soluble carbohydrate contents of 26 and $97 \mathrm{~g} \mathrm{~kg}^{-1}$, respectively, was ensiled in big bales without wilting. The herbage was treated either with no additive (C), with inoculant "Feedtech" (Lactobacillus plantarum and Pediococcus acidilacticci and enzyme Cellulase) (F) at level $1 \times 10^{6} \mathrm{cfu} / \mathrm{g}$ fresh mater and formic acid based additive AIV-2000S (A) at rate of $6 \mathrm{~L} / \mathrm{t}$ fresh matter. During feeding, DM content, chemical composition and fermentation characteristics $(\mathrm{pH}$, lactic acid, VFA, ammonia $\mathrm{N}$ ) in silages were measured weekly. A 126 day feeding experiment was carried out according to the analogue group design. After pre-experimental period (24 days) fifteen Lithuanian Black-and-White bulls (initial liveweight $312 \mathrm{~kg}$ ) were divided into three blocks of 5 animals according to liveweight, and were at random allocated to the treatments within each block. The diet consisted of C, F or A silages that were offered ad libitum and supplemented with concentrate. Ruminal contents were collected by stomach tube from three bulls within each of three different silages and obtained approximately $1.5 \mathrm{~h}$ after feeding, and $\mathrm{pH}$ and ammonia concentrations determined in fresh samples. Aliquots of samples were fixed in formal-saline for protozoa enumeration. Volatile fatty acids, lactate and protein were also determined. In vivo digestibility of silage was studied in trials including four weathers per sample.

\section{RESULTS AND DISCUSSION}

All three silages were well preserved with low ammonia-N and butyric acid contents, but the differences in the fermentation characteristics indicated a more intensive fermentation in $\mathrm{F}$ silage and restricted fermentation in A silage. The content of residual WSC in silages (significantly higher $(\mathrm{P}<0.01)$ in treatment $\mathrm{A}$ ) reflected the extent of fermentation (Table 1$)$. The lower $(\mathrm{P}<0.001)$ production of acetic acid with treatment $\mathrm{F}$ and $\mathrm{A}$ and higher $(\mathrm{P}<0.01)$ production of lactic acid with treatment $\mathrm{F}$ compared with untreated (C) silage indicates a more homolactic type of fermentation with the inoculant.

Mean rumen $\mathrm{pH}$, ammonia-N or total VFA concentration did not differ between the diets (Table 2). The minimum $\mathrm{pH}$ after feeding was lowest with $\mathrm{C}$ silage, and the highest value of ammonia-N was observed with untreated (C) silage. 
Table 1. Chemical composition and fermentation quality of silage

\begin{tabular}{lcccccc}
\hline Indices & $\mathrm{C}$ & $\mathrm{F}$ & $\mathrm{A}$ & $\mathrm{LSD}_{0.05}$ & $\mathrm{LSD}_{0.01}$ & $\mathrm{~S} \overline{\mathrm{x}}$ \\
\hline Dry matter, g kg-1 & 214.50 & $237.27^{* *}$ & $226.90^{* *}$ & 5.018 & 7.035 & 0.72 \\
In dry matter, $\mathrm{g} \mathrm{kg}^{-1} \mathrm{DM}$ & & & & & & \\
$\quad$ crude protein & 146.36 & $165.56^{* *}$ & $167.01^{* *}$ & 11.274 & 15.805 & 2.29 \\
$\quad$ crude fibre & 270.43 & $231.20^{* *}$ & $238.4^{* *}$ & 10.222 & 14.331 & 1.34 \\
$\quad$ WSC & 43.87 & 45.94 & $54.25^{* *}$ & 3.789 & 5.312 & 2.56 \\
$\quad$ total acids & 60.6 & $72.74^{* *}$ & $56.37^{* *}$ & 0.804 & 1.127 & 0.41 \\
lactic acid & 31.50 & $62.84^{* *}$ & $43.20^{* *}$ & 2.542 & 3.564 & 1.80 \\
acetic acid & 25.45 & $8.56^{* *}$ & $12.68^{* *}$ & 1.824 & 2.557 & 3.8 \\
$\quad$ butyric acid & 2.85 & $0.26^{* *}$ & $0.14^{* *}$ & 0.373 & 0.523 & 11.23 \\
$\quad$ ammonia $\mathrm{N}, \mathrm{g} \mathrm{kg}^{-1} \mathrm{~N}$ & 64.2 & $35.42^{* *}$ & 53.62 & 8.871 & 12.436 & 5.64 \\
PH & 4.51 & $4.28^{* *}$ & $4.30^{* *}$ & 0.073 & 0.102 & 0.54 \\
\hline
\end{tabular}

$*$ and $* *$ denotes significant at level 0.05 and 0.01 , respectively

The molar proportion of butyrate was not affected, but the proportion of acetate was significantly lower $(\mathrm{P}<0.05)$ with inoculant treated silage than with $\mathrm{C}$ silage. The proportion of propionic acid was significantly higher $(\mathrm{P}<0.01)$ when $\mathrm{F}$ and $\mathrm{A}$ silages were fed compared with $\mathrm{C}$ silage. The molar proportion of isovalerate was numerically lower in $\mathrm{F}$ diet and significantly lower $(\mathrm{P}<0.05)$ in A diet compared with $\mathrm{C}$ diet. The number of rumen protozoa tended to be higher with A treated silage, but the difference was not significant.

Table 2. Rumen fermentation in cattle (end of exper.) given diets with differently treated silages

\begin{tabular}{|c|c|c|c|c|c|c|}
\hline Indices & $\mathrm{C}$ & $\mathrm{F}$ & A & $\mathrm{LSD}_{0.05}$ & $\mathrm{LSD}_{0.01}$ & $\mathrm{~S} \overline{\mathrm{x}}$ \\
\hline Silage DM intake, $\mathrm{kg} \mathrm{d}^{-1}$ & 7.86 & 8.47 & 8.15 & & & \\
\hline Body weight gain $\mathrm{kg}^{-1} \mathrm{~d}$ & 453.2 & 465.0 & 463.0 & 37.581 & 54.683 & 2.5 \\
\hline \multicolumn{7}{|l|}{ Rumen fermentation: } \\
\hline protozoa, $\times 10^{5} \mathrm{ml}^{-1}$ & 4.49 & 4.54 & 4.98 & 0.613 & 1.017 & 3.34 \\
\hline $\mathrm{pH}$ & 6.77 & 6.74 & 6.74 & 0.282 & 0.467 & 1.06 \\
\hline total VFA, mmol $1^{-1}$ & 95.9 & 98.0 & 96.0 & 10.120 & 16.780 & 2.67 \\
\hline acetate, mol. \% & 61.90 & $57.46^{*}$ & 59.47 & 2.722 & 4.514 & 1.16 \\
\hline propionate, mol. $\%$ & 16.73 & $21.77 * *$ & $21.45 * *$ & 1.622 & 2.689 & 2.07 \\
\hline isobutyrate, mol. \% & 1.68 & 1.50 & 1.33 & 0.305 & 0.505 & 5.16 \\
\hline butyrate, mol. \% & 14.65 & 14.88 & 14.10 & 2.167 & 3.594 & 3.80 \\
\hline isovalerate, mol. \% & 2.05 & 1.68 & $1.47^{*}$ & 0.398 & 0.660 & 5.84 \\
\hline valerate, mol. \% & 1.97 & 1.76 & 1.67 & 0.285 & 0.472 & 4.03 \\
\hline caproate, mol. \% & 1.01 & 0.95 & $0.52 *$ & 0.361 & 0.599 & 11.11 \\
\hline $\mathrm{AP}$ ratio ${ }^{1}$ & 3.70 & $2.64 * *$ & $2.77^{* *}$ & 0.316 & 0.524 & 2.65 \\
\hline $\mathrm{ABP}$ ratio $^{2}$ & 4.57 & $3.33 * *$ & $3.43 * *$ & 0.354 & 0.587 & 2.39 \\
\hline Ammonia-N mmol l-1 & 9.11 & 8.03 & 8.61 & 1.368 & 2.325 & 3.62 \\
\hline
\end{tabular}

* and ** denotes significant at level 0.05 and 0.01 respectively; ${ }^{1} \mathrm{AP}$ ratio - Acetate / Propionate ratio $;{ }^{2} \mathrm{ABP}$ - (Acetate + Butyrate) $/$ Propionate ratio 
When compared to the ruminal fluid from the bulls offered $\mathrm{C}$ silage, the acetate: propionate ratio was significantly lower $(\mathrm{P}<0.01)$ in bulls samples offered $\mathrm{F}$ or A silages. Treatments F and A increased silages DM intake by 0.61 and 0.29 $\mathrm{kg}$ and daily weight gain by 94 and $86 \mathrm{~g}$, respectively, compared with C silage.

Table 3. In vivo digestibility of the experimental silages

\begin{tabular}{lcccccc}
\hline Nutrient & $\mathrm{C}$ & $\mathrm{F}$ & $\mathrm{A}$ & $\mathrm{LSD}_{0.05}$ & $\mathrm{LSD}_{0.01}$ & $\mathrm{~S} \overline{\mathrm{x}}$ \\
\hline Organic matter & 62.2 & 66.1 & 66.2 & 3.647 & 6.048 & 1.43 \\
Crude protein & 60.1 & 60.5 & $64.3^{*}$ & 3.299 & 5.471 & 1.36 \\
Crude fat & 67.4 & 68.1 & 68.4 & 3.718 & 6.166 & 1.39 \\
Crude fibre & 54.3 & 59.2 & 57.3 & 4.827 & 8.004 & 2.16 \\
Nitrogen free extractives & 61.3 & 65.2 & 64.3 & 3.731 & 6.187 & 1.49 \\
\hline
\end{tabular}

* denote significant at level 0.05

Digestibility of crude protein was significantly higher $(\mathrm{P}<0.05)$ with treatment $\mathrm{A}$ and digestibility of crude fibre was numerically higher with treatment $\mathrm{F}$ than with treatment C (Table 3). Selmer-Olsen et al. (1997) found that silage additives have effect on nutrient digestion.

\section{CONCLUSIONS}

When compared to the ruminal fluid from the bulls offered $\mathrm{C}$ silage, the acetate:propionate ratio was significantly lower $(\mathrm{P}<0.01)$ in rumen fluid from bulls offered F or A silages.

The results confirmed that when silage fermentation and digestibility were improved by use of inoculant or when silage fermentation was restricted by use of an acid additive, silage intake and daily weight gain of fattening bulls had increased compared with untreated silage.

\section{REFERENCES}

Cushnahan A., Mayne C.S., Unsworth E.F., 1995. Effects of ensilage of grass on performance and nutrient utilisation by dairy cattle. 2 . Nutrient metabolism and rumen fermentation. J. Anim. Sci. 60, 347-359

Jaakkola S., Huhtanen P., Hissa K., 1991. The effect of cell wall degrading enzymes or formic acid on fermentation quality and on digestion of grass silage by cattle. Grass Forage Sci. 46, 75-87

Krzywiecki S., Szyrner A., Pasternak A., 2003. Effect of whole-crop grain silage on fermentation processes and micro flora status in the rumen. Proceedings $11^{\text {th }}$ International Scientific Symposium "Forage Conservation" Nitra (Slovak Republik), pp. 164-165

McDonald P., Henderson A.R., Heron S.J. (Editors), 1991. The Biochemictry of Sigale. $2^{\text {nd }}$ Edition. Chalcombe Publications, Aberrystwyth (UK), pp. 340

Selmer-Olsen J., Mo M., 1997. The effects of three different silage additives on the extent of silage fermentation and the performance of dairy cows. Acta Agr. Scand., Sect. A, Anim. Sci. 47, 148-158 